\title{
Treatment of Pretreated Landfill Leachate by Membrane Bioreactor Process
}

\author{
Swathy P.S, Habeeba. V
}

Department of Civil Engineering, Malabar College of Engineering and Technology, Thrissur-679532, Kerala, India

\begin{abstract}
Landfill leachate is a liquid that is mainly produced by the rain which falls on the solid waste. The leachate usually contains high concentrations of ammonium, organic matter, toxic compounds and heavy metals, which makes it unsuitable for discharge in natural bodies without any prior treatment. The formation of leachate threatens the groundwater, soil and environment. Land filling is the one of the least expensive method for disposal of municipal solid waste (MSW). In this study, landfill leachate is treated by coagulation and Membrane Bioreactor (MBR) process by using ultrafiltration (UF). The original sample has BOD/COD ratio as 0.603. Coagulation was used as a pretreatment prior to the biological treatment. . It was done by using alum as an coagulant at an optimum dosage of $160 \mathrm{mg} / \mathrm{L}$. Coagulation has proven effective as a pretreatment. But the effluent quality did not meet the general standards for discharge of environmental pollutants. So the effluent after coagulation process was treated by MBR process. In this study, after MBR treatment all the parameters except BOD have met the relevant Indian Standards for discharge as irrigation water.
\end{abstract}

Keywords - Coagulation, Leachate, Membrane Bioreactor Process, Municipal Solid Waste, Ultrafiltration.

\section{INTRODUCTION}

Waste is material that is no longer useful or valuable for society. Looking back in time, the waste management first became a problem in densely populated areas, such as villages and towns. A poor waste management leads to sanitary and aesthetical issues. One commonly used waste management method is to dispose the waste in a landfill. There are environmental downsides of disposing waste in a landfill, even if it is constructed with modern practice. The waste in the landfill is degraded during the production of greenhouse gases, such as methane.

Percolation of precipitation and groundwater flowing into the landfill create leachate, contaminated water.

Sanitary Landfill is considered to be the most common way of disposing urban solid wastes. An important problem associated with sanitary landfills is the production of leachate. Leachate is generally formed when rain water percolates through dumped waste and takes up the organic and inorganic products by both physical extraction and hydrolytic and fermentation processes. Generally, leachate contains high concentrations of soluble organic matter and inorganic ions. Due to its high strength and its impact on environment, direct discharge of leachate into the environment is not recommended.

Presently in India, little attention is made to landfill leachate treatment and even less attention to treat the produced sludge while treating leachate. Leachate Channeling (Combined treatment with domestic sewage, Recycling and lagooning), Biological Processes (Aerobic and Anaerobic) and Chemical/ Physical Treatment (Chemical precipitation, Chemical oxidation, Adsorption, membrane technology and stripping of $\mathrm{NH}_{3}$ ) are some of the leachate treatment methods.

This study consists of two methods, namely physicochemical treatment and biological treatment. In the lab scale, the general treatment is simulated by Membrane bioreactor (MBR). MBR, though not widely used as a general treatment technique at present in developing countries, has future prospects of wide application as the cost of membranes are coming down.

\section{MATERIALS AND METHODS}

\subsection{Leachate}

The landfill leachate sample was collected from Municipal Solid Waste Disposal Facility at Brahmapuram, Kochi. The landfill leachate samples from the sites were collected in sterile bottles. The bottles were labeled with the date and time of sampling. Samples were immediately transferred to the laboratory and stored at $4^{\circ} \mathrm{C}$. Their main physicochemical characteristics are analyzed.

Table.1: Landfill leachate characteristics

\begin{tabular}{|l|l|l|l|}
\hline Sl.No. & Parameters & Unit & Value \\
\hline 1. & Ph & - & 5.0 \\
\hline 2. & BOD & $\mathrm{mg} / \mathrm{L}$ & 30800 \\
\hline 3. & COD & $\mathrm{mg} / \mathrm{L}$ & 51060 \\
\hline 4. & TSS & $\mathrm{mg} / \mathrm{L}$ & 8635 \\
\hline 5. & TDS & $\mathrm{mg} / \mathrm{L}$ & 18590 \\
\hline 6. & Turbidity & NTU & 1230 \\
\hline 7. & Chloride & $\mathrm{mg} / \mathrm{L}$ & 4551.7 \\
\hline
\end{tabular}




\begin{tabular}{|l|l|l|l|}
\hline $\mathbf{8 .}$ & Ammonia nitrogen & $\mathrm{mg} / \mathrm{L}$ & 3800 \\
\hline $\mathbf{9 .}$ & Phosphate & $\mathrm{mg} / \mathrm{L}$ & 720 \\
\hline $\mathbf{1 0 .}$ & Sulphate & $\mathrm{mg} / \mathrm{L}$ & 5600 \\
\hline 11. & Sulphide & $\mathrm{mg} / \mathrm{L}$ & 415 \\
\hline 12. & Potassium & $\mathrm{mg} / \mathrm{L}$ & 3625 \\
\hline
\end{tabular}

\subsection{Preparation of Synthetic Wastewater}

Synthetic leachate was prepared based on the data obtained from previous studies. The composition of synthetic sample was prepared by trial and error method so that reasonable match with the sample could be obtained.

Table .2: Composition of synthetic sample (Anisha Suresh

\begin{tabular}{|c|c|}
\multicolumn{2}{c}{ et al., 2016) } \\
\hline Chemicals Required & Quantity in grams/ litre \\
\hline Ammonium chloride & 3.2 \\
\hline Sodium sulphide & 2.2 \\
\hline Sodium chloride & 3.2 \\
\hline Calcium carbonate & 0.38 \\
\hline $\begin{array}{c}\text { Dipotassium hydrogen } \\
\text { ortho phosphate }\end{array}$ & 0.8 \\
\hline Ferrous sulphate & 0.24 \\
\hline Magnesium sulphate & 0.24 \\
\hline D- Glucose & 28 \\
\hline
\end{tabular}

\subsection{Jar Test}

Coagulation experiments were performed by using a conventional jar-test apparatus equipped with five 1,000$\mathrm{ml}$ beakers at room temperature. Alum was used as coagulant in this study. Coagulant dosage was optimized by performing the experiments at varying coagulant dosage at optimum $\mathrm{pH}$. The beakers were labeled and kept in jar apparatus and stirred at $200 \mathrm{rpm}$ for $3 \mathrm{~min}$ and at $60 \mathrm{rpm}$ for $20 \mathrm{~min}$, and is, then, allowed to settle for 30 min. The first run was done by adding different doses of Alum as 100, 120, 140, 160, $180 \mathrm{mg} / \mathrm{l}$ to the samples. To evaluate the efficiency of Coagulation, turbidity of leachate were measured before and after the treatment.

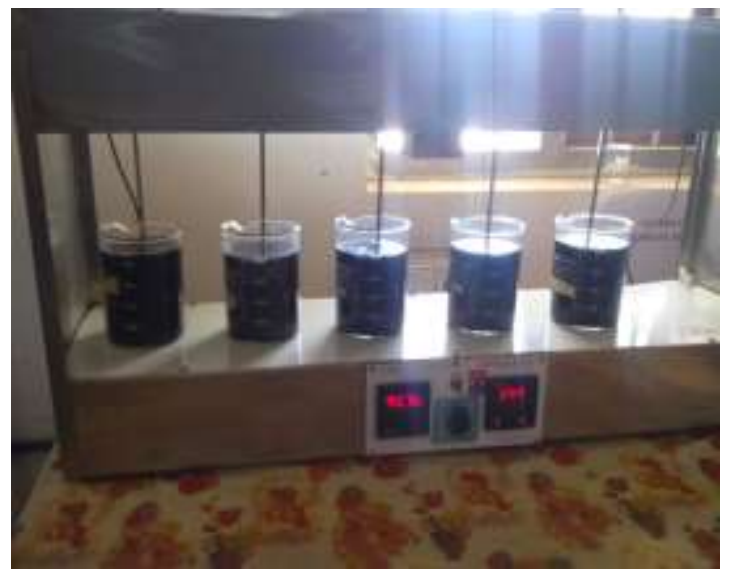

Fig.1 : Jar Test Apparatus with Leachate Samples

\subsection{Process in MBR}

An acrylic container of $8 \mathrm{~L}$ capacity was used as the bioreactor. The size of the reactor was $20 \mathrm{~cm} \mathrm{x} 16 \mathrm{~cm} \mathrm{x}$ $25 \mathrm{~cm}$. The reactor was supplied with oxygen by aerator. Aeration rate of 3litre/min was provided. The membrane arrangement consist of membrane module having pore size of $0.5 \mu \mathrm{m}$, pump of capacity $1.5 \mathrm{lpm}$ and DC adapter connected in series.

Bio sludge collected from a secondary sedimentation tank from a dairy plant was acclimatized with leachate for 1 month. The reactor was operated in batch mode which was filled with $1 \mathrm{~L}$ sludge and $3 \mathrm{~L}$ leachate in order to maintain the MLSS concentration in the range $18 \mathrm{~g} / \mathrm{L}$. After the reaction time, mixed liquor was allowed to settle for 30 minutes. The supernatant from the bioreactor was passed through the hollow fibre membrane module using a pump of capacity $1.5 \mathrm{lpm}$. The treated effluent was collected and analyzed

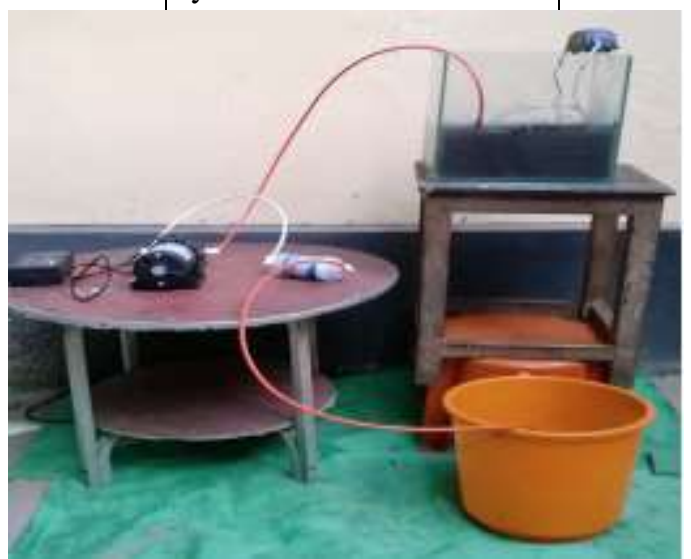

Fig. 2 : Experimental setup of $M B R$

\section{RESULTS AND DISCUSSIONS}

3.1 Determination of Optimum Coagulant Dosage and Hydraulic Retention Time (HRT)

Coagulation is used as the pretreatment method for the leachate and alum was used as the coagulant. Coagulation test was carried out using jar test. By chemical treatment using alum with different doses the best removal efficiency of $94.9 \%$ has been achieved at an alum dose of $160 \mathrm{mg} / \mathrm{L}$. This alum concentration has been used as the optimum coagulant dosage for the treatment of leachate.

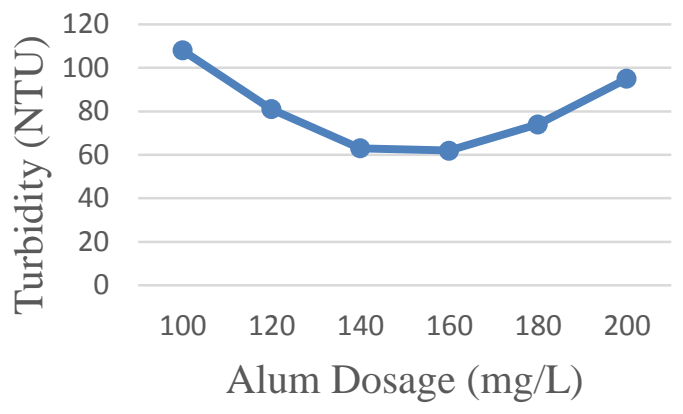

Fig. 3: Determination of Optimum Coagulant Dosage The synthetic wastewater was subjected to activated sludge process at neutral $\mathrm{pH}$ in the bioreactor. The 
optimum HRT was obtained by analyzing the COD removal efficiency in each day.

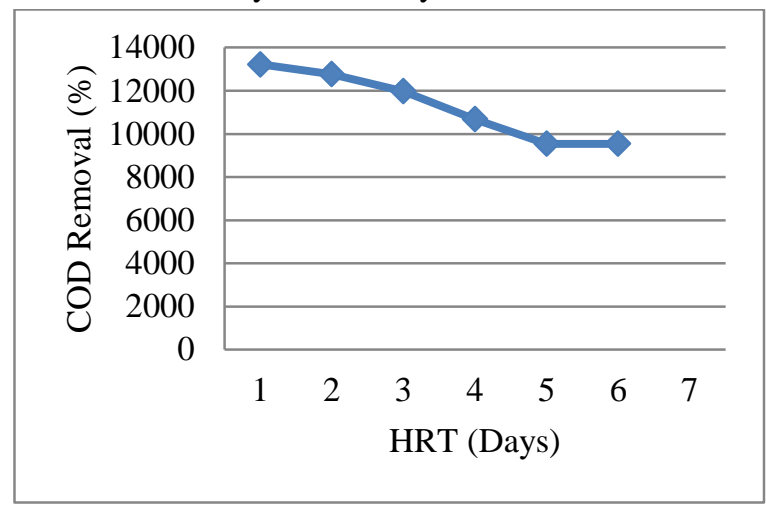

Fig.4: COD removal at different HRTs

So the leachate sample was treated by coagulation process with an optimum coagulant dosage of $160 \mathrm{mg} / \mathrm{l}$ and MBR with an optimum HRT of 5 days.

\subsection{Pretreatment of Leachate by Coagulation}

Leachate was pretreated by coagulation process with an optimum coagulant dosage of $160 \mathrm{mg} / \mathrm{l}$ and at neutral $\mathrm{pH}$. The removals of various parameters by coagulation process were studied.

Table.3: Percentage removal of pollutants after pretreatment (coagulation)

\begin{tabular}{|c|c|c|c|}
\hline $\begin{array}{c}\text { Parameters } \\
(\mathrm{mg} / \mathrm{L})\end{array}$ & $\begin{array}{c}\text { Concentrati } \\
\text { on of } \\
\text { Parameters } \\
\text { before } \\
\text { pretreatme } \\
\mathrm{nt}\end{array}$ & $\begin{array}{c}\text { Concentra } \\
\text { tion of } \\
\text { Parameter } \\
\text { s after } \\
\text { pretreatme } \\
\text { nt }\end{array}$ & $\begin{array}{c}\% \\
\text { Rem } \\
\text { ovel }\end{array}$ \\
\hline BOD & 30800 & 8008 & 74 \\
\hline COD & 51060 & 11743.8 & 77 \\
\hline TSS & 8635 & 1554.3 & 82 \\
\hline TDS & 18590 & 3532.1 & 81 \\
\hline $\begin{array}{c}\text { Turbidity } \\
(\text { NTU) }\end{array}$ & 1230 & 86.1 & 93 \\
\hline Chloride & 4551.7 & 773.78 & 83 \\
\hline $\begin{array}{c}\text { Ammonia } \\
\text { nitrogen }\end{array}$ & 3800 & 532 & 86 \\
\hline Phosphate & 720 & 151.2 & 79 \\
\hline Sulphate & 5600 & 1008 & 82 \\
\hline Sulphide & 415 & 124.5 & 70 \\
\hline Potassium & 3625 & 906.25 & 75 \\
\hline
\end{tabular}

From the above Table 3 it is clear that coagulation as a pretreatment is efficient to operate. The percentage removals of BOD, COD, TSS, TDS, turbidity, chloride, ammonia nitrogen, phosphate, sulphate, sulphide and potassium were $74 \%, 77 \%, 82 \%, 81 \%, 93 \%, 83 \%, 86 \%$, $79 \%, 82 \%, 70 \%$ and $75 \%$ respectively.

3.3 Treatment of Leachate by MBR Process

The pretreated leachate sample was passed through MBR process for the secondary treatment at an optimum HRT of 5 days. The removals of various parameters by MBR process were studied.

Table. 4 : Percentage removal of pollutants after $M B R$

\begin{tabular}{|c|c|c|c|}
\hline $\begin{array}{c}\text { Parameters } \\
(\mathrm{mg} / \mathrm{L})\end{array}$ & $\begin{array}{c}\text { Conc. of } \\
\text { Parameters } \\
\text { before MBR }\end{array}$ & $\begin{array}{c}\text { Conc. of } \\
\text { Parameters } \\
\text { after MBR }\end{array}$ & $\begin{array}{c}\% \\
\text { Rem } \\
\text { ovel }\end{array}$ \\
\hline BOD & 8008 & 960.9 & 87 \\
\hline COD & 11743.8 & 1761.6 & 85 \\
\hline TSS & 1554.3 & 139.9 & 91 \\
\hline TDS & 3532.1 & 353.2 & 90 \\
\hline $\begin{array}{c}\text { Turbidity } \\
(\text { NTU) }\end{array}$ & 86.1 & 5.2 & 94 \\
\hline Chloride & 773.78 & 85.1 & 89 \\
\hline $\begin{array}{c}\text { Ammonia } \\
\text { nitrogen }\end{array}$ & 532 & 37.2 & 93 \\
\hline Phosphate & 151.2 & 6 & 96 \\
\hline Sulphate & 1008 & 100.8 & 90 \\
\hline Sulphide & 124.5 & 13.7 & 89 \\
\hline Potassium & 906.25 & 326.3 & 91 \\
\hline
\end{tabular}

The membrane can capture most of the suspended solids in the reactor because of its fine pore size. Therefore, non-biodegradable organic compounds are removed through filtration of particulates and discharge sludge. The percentage removal increases after MBR process. The percentage removals of BOD, COD, TSS, TDS, turbidity, chloride, ammonia nitrogen, phosphate, sulphate, sulphide and potassium were $87 \%, 85 \%, 91 \%$, $90 \%, 94 \%, 89 \%, 93 \%, 96 \%, 90 \%, 89 \%$ and $91 \%$ respectively.

Table.5: Evaluation of performance of MBR process after pretreatment in leachate based on relevant Indian Standards

\begin{tabular}{|c|c|c|c|}
\hline \multirow[t]{2}{*}{$\begin{array}{l}\text { Parameters } \\
(\mathrm{mg} / \mathrm{L})\end{array}$} & \multirow[t]{2}{*}{$\begin{array}{l}\text { Final Effluent } \\
\text { Characteristics }\end{array}$} & \multicolumn{2}{|c|}{$\begin{array}{l}\text { General standards } \\
\text { for discharge of } \\
\text { environmental } \\
\text { pollutants as per } \\
\text { The Environment } \\
\text { (Protection) Rules, } \\
\text { 1986, Govt. of } \\
\text { India }\end{array}$} \\
\hline & & $\begin{array}{c}\text { Into } \\
\text { surface } \\
\text { water }\end{array}$ & $\begin{array}{l}\text { To land } \\
\text { for } \\
\text { irrigation }\end{array}$ \\
\hline BOD & 960.9 & $<30$ & $<100$ \\
\hline COD & 1761.6 & $<250$ & ----- \\
\hline TSS & 139.9 & $<100$ & $<200$ \\
\hline TDS & 353.2 & $<1500$ & ---- \\
\hline $\begin{array}{l}\text { Turbidity } \\
\text { (NTU) }\end{array}$ & 5.2 & $<40$ & ---- \\
\hline Chloride & 85.1 & $<1000$ & $<600$ \\
\hline
\end{tabular}




\begin{tabular}{|c|c|c|c|}
\hline $\begin{array}{c}\text { Ammonia } \\
\text { nitrogen }\end{array}$ & 37.2 & $<50$ & ----- \\
\hline Phosphate & 6 & $<2$ & ---- \\
\hline Sulphate & 100.8 & $<1000$ & $<1000$ \\
\hline Sulphide & 13.7 & $<2$ & ----- \\
\hline Potassium & 326.3 & $<30$ & ---- \\
\hline
\end{tabular}

The Table 5 summarizes the result of all treatment done using original leachate. The table shows the performance of coagulation and membrane bioreactor process based on the relevant Indian Standards. These standards are inserted by the Govt. of India by Rule 2(d) of the Environment (Protection) Second Amendment Rules, 1993 notified vide G.S.R. 422(E) dated 19.05.1993, published in the Gazette No. 174 dated 19.05.1993.The table shows that final treated effluent have not met all the relevant standards. The value of BOD, COD, phosphate, TSS and sulphide is not within the limit and has not met the standards of discharge into surface water. So the effluent could not be discharged into surface water. After all treatments, all the parameters of the effluent except BOD have met the standards of discharge as irrigation water.

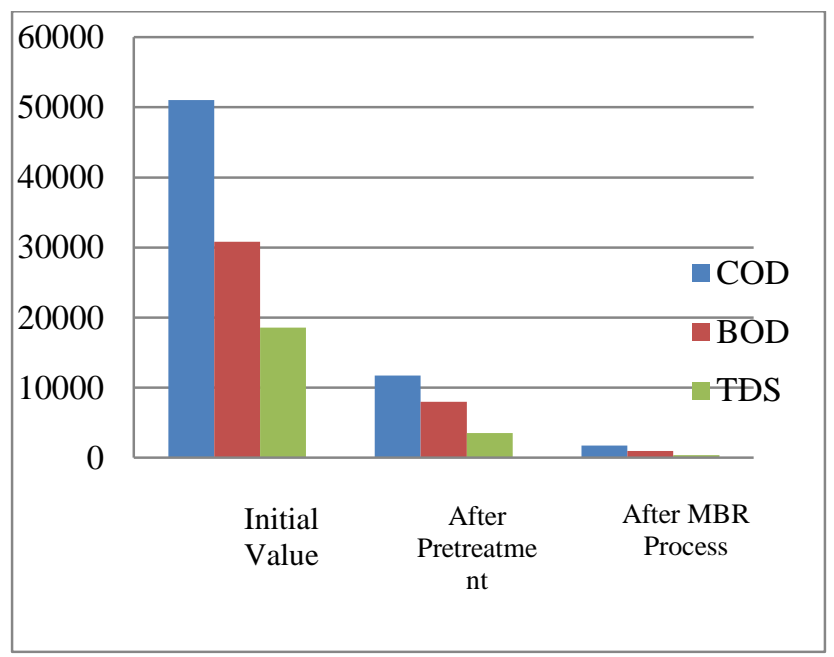

Fig.5: Comparison of effeciency of treatment process for $C O D, B O D$ and TDS removal

After pretreatment the removal percentages were $77 \%$, $74 \%$ and $81 \%$ for COD, BOD and TDS respectively. The removal ratios has increased to $85 \%, 87 \%$ and $90 \%$ for those parameters after MBR process.

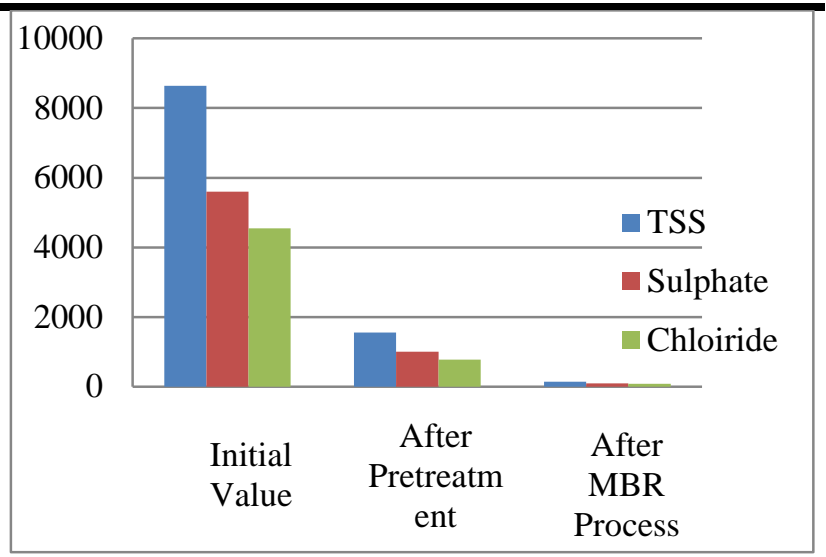

Fig. 6 : Comparison of treatment process for TSS, Sulphate and Chloride removal

The removal ratios of TSS, sulphate and chloride has increased from $82 \%, 82 \%$ and $83 \%$ to $91 \%, 90 \%$ and $89 \%$ after MBR process.

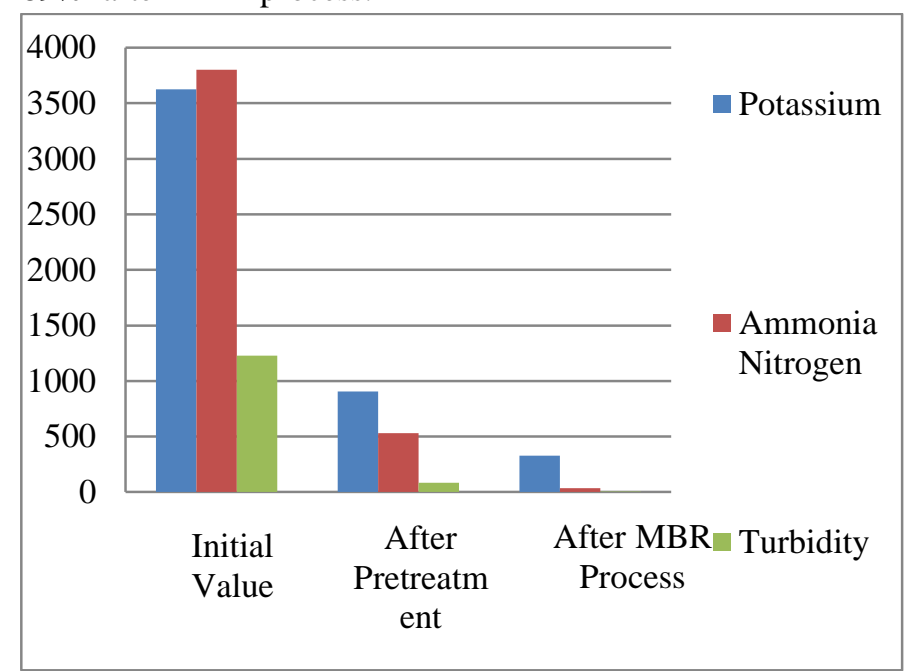

Fig. 6 : Comparison of treatment process for Potassium, Ammonia Nitrogen and Turbidity removal

After pretreatment the removal percentages were $75 \%$, $86 \%$ and $93 \%$ for potassium, ammonia nitrogen and turbidity respectively. After MBR process, 91\%, 93\% and $94 \%$ removal ratios were obtained.

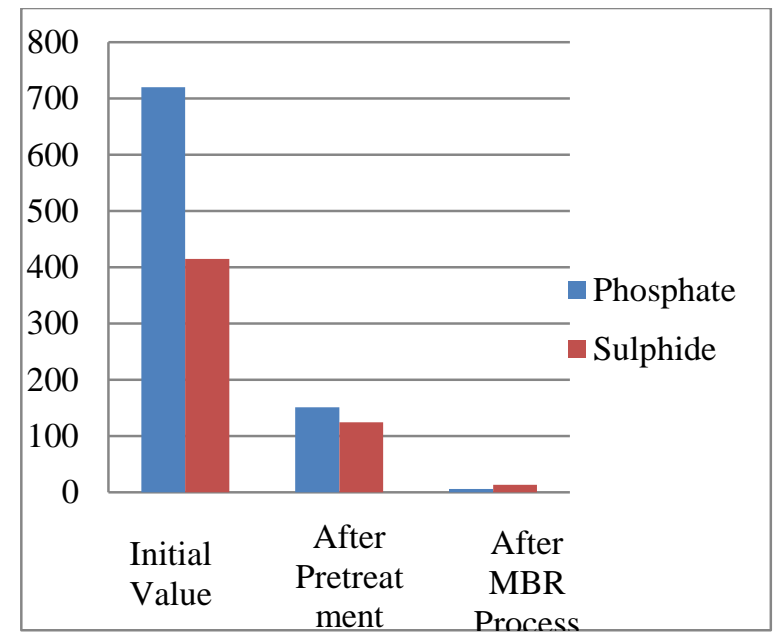

Fig. 7 : Comparison of treatment process for Phosphate and sulphide removal 
The removal ratios of phosphate and sulphide has increased from $79 \%$, and $70 \%$ to $96 \%$, and $89 \%$ after MBR process.

\section{CONCLUSIONS}

In this study, landfill leachate was treated by coagulation as a pretreatment and MBR process in order to meet the effluent discharge standards.

The sample was pretreated by coagulation with an Optimum coagulant dosage of $160 \mathrm{mg} / \mathrm{L}$. In case of MBR process the sample was treated with an optimum HRT of 5 days and at neutral $\mathrm{pH}$ in batch mode. After coagulation process the percentage removal obtained for BOD, COD, TSS, TDS, turbidity, chloride, ammonia nitrogen, phosphate, sulphate, sulphide and potassium were $74 \%$, $77 \%, 82 \%, 81 \%, 93 \%, 83 \%, 86 \%, 79 \%, 82 \%, 70 \%$, and $75 \%$ respectively. The percentage removal obtained for BOD, COD, TSS, TDS, turbidity, chloride, ammonia nitrogen, phosphate, sulphate, sulphide and potassium after MBR treatment were 96.9\%, 96.5\%, 98\%, 98\%, $99.5 \%, 98 \%, 99 \%, 99 \%, 98 \%, 96.7 \%$ and $91 \%$ respectively. From the result it can be seen that percentage removal of pollutants increased after MBR treatment. But final treated effluent has not met all the relevant Indian Standards for discharge in to surface water. But for discharging as irrigation water all the parameters except BOD has met the relevant Indian Standards. So the final treated effluent can be used as irrigation water after doing a post treatment. So it can be concluded that coagulation process can be used as a pretreatment of MBR system. It gives high percentage removal of pollutants.

\section{ACKNOWLEDGEMENTS}

This research was supported by Malabar College of Engineering and Technology, Thrissur, Kerala.

\section{REFERENCES}

[1] Abdulhussain A. Abbas et al. (2009) 'Review on Landfill Leachate Treatments', American Journal of Applied Sciences, Vol. 6, No. 4, October 2009, pp. 672-684.

[2] Ahmet Altin (2008) 'An alternative type of photo electro-Fenton process for the treatment of landfill leachate', Separation and Purification Technology, Vol. 61, July 2007, pp. 391-397.

[3] Alessandra Cesaro et al. (2013) 'Wastewater Treatment by Combination of Advanced Oxidation Processes and Conventional Biological Systems', $J$ Bioremed Biodeg, Vol. 4, No. 8, 2013, pp. 1-8.

[4] Amr M. Abdel Kader (2007) 'A Review of Membrane Bioreactor (MBR) Technology and their Applications in the Wastewater Treatment Systems', Eleventh International Water Technology
Conference, IWTC11 2007 Sharm El-Sheikh, Egypt, Vol. 4, No. 5, pp. 269-279.

[5] Anisha Suresh et al. (2016) 'Treatment of Landfill Leachate by Membrane Bioreactor and Electro fenton process', International Journal of Engineering Sciences \& Research Technology, Vol. 5, No. 8.

[6] Asha Sivan and Latha P. (2013) 'Treatment of Mature Landfill Leachate from Vilappilsala by Combined Chemical and Biological Process', International Journal of Innovative Research in Science, Engineering and Technology, Vol. 2, No. 9, September 2013, pp. 4405-4414.

[7] Asli Coban et al. (2012) 'Advanced Treatment of Leachate By Using Aerobic/Anoxic MBR System Followed by a Nano filtration Process. A Case Study in Istanbul Komurcuoda Leachate Treatment Plant', Environment Protection Engineering, Vol. 38, No. 3, November 2012, pp. 57-64.

[8] Chi Kim Lim et al. (2016) 'Treatment of landfill leachate using ASBR combined with zeolite adsorption technology', Chemical Papers- Slovak Academy Of Sciences, Vol. 8, No. 6, August 2016, pp. 82-87.

[9] Choi, H et al. (2005) 'Effect of permeate flux and tangential flow on membrane fouling for wastewater treatment', J. Separation and Purification Technology, Vol. 4, pp. 68-78.

[10]Dao-Bin Zhang et al. (2014) 'Landfill leachate treatment using the sequencing batch biofilm reactor method integrated with the electro- Fenton process', Chemical Papers- Slovak Academy Of Sciences, Vol. 68, No. 6, June 2014, pp. 782-787.

[11]Devendra Dohare and Rohit Trivedi (2014) 'A Review on Membrane Bioreactors: An Emerging Technology for Industrial Wastewater Treatment', International Journal of Emerging Technology and Advanced Engineering, Vol. 4, No. 12, December 2014, pp. 226-236.

[12] Durr-E-Shahwar et al. (2012) 'Solar Assisted Photo Fenton for Cost Effective Degradation of Textile Effluents in Comparison to AOPs', Global NEST Journal, Vol. 14, No. 4, April 2012, pp. 477-486.

[13]Elena Cristina Rada et al. (2013) 'Analysis of Electro-Oxidation Suitability for Landfill Leachate Treatment through an Experimental Study', Sustainability, Vol. 5, September 2013, pp. 39603975.

[14]Elena Maranon et al. (2009) 'Tertiary treatment of landfill leachates by adsorption', International Journal of Innovative Research in Science, Engineering and Technology, Vol. 2, No. 8, July 2009, pp. 4405-4414. 
[15] Enric Brillas (2014) 'A Review on the Degradation of Organic Pollutants in Waters by UV Photo electro-Fenton and Solar Photo electro-Fenton', J. Braz. Chem. Soc., Vol. 25, No. 3, 2014, pp. 393-417.

[16] E. S. Koumaki et al. (2011) 'Treatment of Landfill Leachate by Adsorption on Powdered (PAC) and Granular (GAC) Activated Carbon', International Conference on Environmental Science and Technology, Vol. 23, September 2011, pp. 3-8.

[17] Eyup Atmaca (2009): 'Treatment of landfill leachate by using electro-Fenton method', Journal of Hazardous Materials, Vol. 163, June 2008, pp. 109114. 